\title{
Animals Finally above Objects and Stricter Criminalization of Cruelty: Some Insights in Czech Animal Legislation
}

\section{Hana Müllerová ${ }^{1}$}

\section{Introduction}

The legal protection of animals of the Czech Republic has its roots as far back as in early 20th century with the first anti-cruelty provisions of the then Czechoslovakia. Nevertheless, the 40years long communist regime, which lasted until 1989, brought discontinuance in all the law system including animal protection. Thus, completely new animal protection legislation came during the first decade of building a democratic legal system, which was at the same time the decade of preparing our country to the European Union accession in 2004. Today, the legal background of animal protection in the Czech Republic is of a high standard; however, there are minor legislative and administrative imperfections that cause application problems and lower the effectiveness of the animal protection. Initially, this paper introduces basic features of the current Czech animal protection legislation and draws attention to the new Czech legal status of non-human animals. However, the main target of the author is to give a detailed picture of the Czech anti-cruelty legislation; the survey is supported by a short insight in rules of handling stray animals to illustrate the Czech legal approach to companion animals' protection.

\section{Structure and legislative background of animal protection.}

The Czech legal protection of animals entails three main parts: 1. protection of animals against cruelty; 2. protection of individual categories of animals (e.g. farm animals, companion animals, or handicapped animals); 3. protection of all vertebrates during individual human activities with them (e.g. during performing animals in public, operating animal shelters, experimenting, transporting, or slaughtering). The whole sector of animal protection is administered under the leading of the Ministry of Agriculture; the Ministry publishes annually a document called Animal Protection Programme ${ }^{2}$.

1 JUDr. Hana Müllerová, Ph.D. (mullerova@ilaw.cas.cz), graduated from the Faculty of Law, Charles University in Prague, Czech Republic. She worked in the Legislative Department of the Ministry of Environment. At present she occupies a researcher position in the field of environmental law in the Institute of State and Law of the Czech Academy of Sciences, Prague. This paper was written for Derecho Animal web center, February 2012.

2 See http://eagri.cz/public/web/en/mze/. The Animal Protection Programme is available also in English. See http://eagri.cz/public/web/file/127432/POZ2010 tisk.pdf. 
The mass of the Czech animal protection legislation is covered by several laws of different sort. Firstly, the core of this legislation is given by the Animal Welfare Act (AWA) ${ }^{3}$. It is a complex act from 1992, applied to all vertebrates (and only to vertebrates). In 30 multiparagraph sections, the AWA covers:

bans on cruelty to animals and on groundless killing animals;

detailed rules of breeding, transporting and slaughtering farm animals, carrying public performances with animals, handling stray and abandoned animals, protecting wild animals and handicapped animals, and conducting animal experiments.

Secondly, two additional pieces of legislation concern certain specific subtopics of the animal protection: the Veterinary Act ${ }^{4}$, setting the animal health requirements, and the Penal $\mathrm{Code}^{5}$, criminalizing the most serious cases of animal cruelty. Finally, the Czech Civil Code determines the legal status of non-human animals.

\section{Legal status of animals}

From 2014, animals will no longer be objects in legal sense in the Czech Republic. Thanks to the new Czech Civil Code, approved in February 2012 and coming in force in two years, the Czech Republic has finally joined the countries that had already reflected in law the ongoing ethical shift of human relations to other living beings that are also capable to experience pain and suffering. This change is widely accepted within the society. The new Civil Code contains an explicit statement in section 494 "Living animals have special importance and value as living creatures endowed by senses. Living animals are not objects; provisions regarding objects are to be applied to animals only if this application does not contravene with the nature of the animal." The new legal status of animals will apply not only within the civil law, but throughout the whole Czech legal system. What is more, it will cover not only vertebrates, but all non-human animals.

\section{Protection of animals against cruelty}

\section{Notion of cruelty in the Czech law}

The AWA prohibits any form of cruelty to animals as well as any promotion of cruelty ${ }^{6}$. The AWA defines, what exactly cruelty to animals means. In section 4 , individual practices that are all considered as cruelty to animals, are enumerated. The list of these practices in section 4 is rather long (including 23 items) and each prohibited activity is described in detail ${ }^{7}$. What is more, this list of prohibited activities is not exhaustive. On the contrary, it is "open", because,

\footnotetext{
3 Act No. 246/1992 Sb., on protection of animals against cruelty, as amended (Animal Welfare Act). Available in English at: http://eagri.cz/public/web/file/10666/AZ246_92_OZ_uz.pdf. Unfortunately, the English translation published at the site mentioned is not fully updated.

4 Act No 166/1999 Sb., on veterinary care and amending certain related laws (Veterinary Act).

5 Act. No. 40/2009 Sb., Penal Code.

6 §2(1)and(2)oftheAWA.
} 
in accordance with the last item of the list, cruelty is also any other activity than described in previous items if it contravenes the AWA and causes animal suffering. This form of cruelty definition makes it possible to prosecute also other types of human behaviour causing harm to animals, than those explicitly mentioned in section 4 . On the other hand, apart from these pros mentioned, there is also a con of the Czech anti-cruelty legislation: as the AWA's scope covers only vertebrates, the non-vertebrates are not at all protected against cruelty in the Czech Republic.

\section{Animal hoarding}

To supplement the matter, animal hoarding is not enumerated among animal cruelty activities in section 4 and thus, it is not as such legally forbidden in the Czech Republic. A future ban on keeping more than a certain number of animals is even not expected in the Czech Republic, and cases of animal hoarders are assessed pursuant to the existing definition of animal cruelty if needed. It means that the breeding conditions, appropriate feeding and watering supplements, health or stress of animals and other aspects of their welfare are inspected. Regarding farm animals, the veterinary authority may charge the keeper to decrease his or her animal community if the breeding conditions are poor. The amendment of the AWA, which is currently under preparation, plans to extend this entitlement of the veterinary administration to all animals, including companion animals. ${ }^{8}$

\footnotetext{
7 Here are some examples of practices considered as cruelty to animals under $\S 4$ of the AWA: to force an animal to perform tasks, which are not appropriate with regard to its physical condition and biological characteristics and which are apparently beyond its natural capacities; to train an animal or make an animal perform at public performances or similar events, if it entails pain, suffering, injury or other damage to the animal, as well as to raise, train or purposefully use the animal for aggression against man or against other animals; to restrict for other than therapeutic purposes the provision of feed to the animal, including water, unless stipulated otherwise by special legislation; to train or test an animal on another live animal, except for training of a hunting bird of prey; to carry out surgical procedures in order to change the appearance or other characteristics of an animal, namely also in cases when the referred to procedures would be carried out with the use of general or local anaesthesia, pain killers or other methods; to cause without any reason undue stress of biological, physical or chemical nature; to keep animals under inappropriate conditions or in such a way they may cause suffering to themselves or to each other.
}

\footnotetext{
${ }^{8}$ The amendment of the AWA prepared by the Ministry of Agriculture aims particularly to implement the new European Union legislation on animal experiments; nevertheless, in the current early stage it looks very promising also as to bring many small but significant improvements into the animal protection standard and to eliminate some of the barriers of effective animal laws application. However, it is not possible to anticipate the results of the legislative process because the parliamentary discussions often lead to even extensive changes within the bills in the Czech Republic.
} 


\section{Investigation of cruelty}

The investigation of cases of animal cruelty takes its course either within the form of administrative procedure held by municipal authorities or, as regards crimes, within the form of criminal procedure held by police, prosecution and court. Regional veterinary administrations always cooperate; they often even initiate opening administrative or criminal proceedings if their inspection findings indicate so. The role of veterinary inspectors in those proceedings is crucial: they give their expert opinions on veterinary and animal cruelty aspects of the matter. It is also the police that can effectively contribute to solve animal cruelty cases. Policemen have a special power pursuant to the Czech Act on the Police: in case of a strong suspicion of animal abuse, they are entitled to enter a plot or another space (which is interpreted as for example a car, a garage, or a garden house) without the consent of the owner ${ }^{9}$. Nevertheless, there is no legal way for the police to enter a dwelling (a house or a flat) by force in such situations. The amendment of the AWA mentioned intends to change this insufficiency by enabling the police to enter a dwelling, too.

\section{Prosecution of cruelty}

Cruelty to animals is to be prosecuted either as an administrative offence (as an infraction or an administrative tort) under the AWA or, if more serious, as a crime under the Penal Code.

The previous Penal Code of 1961 did initially not criminalized animal cruelty at all. The amendment of that Code brought for the first time the crime of animal cruelty in 1993 and at that time, the formulation of the crime was rather moderate to the perpetrators: only repeated serious intentional animal cruelty was a crime. Today, our new Penal Code of 2009 distinguishes two animal cruelty crimes: an intentional form of cruelty ("cruelty to animals") and a form committed by negligence ("inappropriate care of animals") ${ }^{10}$.

The punishments for each type of a delict became stricter over the last decade: For an administrative offence a fine up to $500.000 \mathrm{CZK}$ (approx. $€ 20.000$ ) can be imposed. For an intentional animal-cruelty crime, an imprisonment up to 3 years can be imposed; in case of a negligent culpability crime, the imprisonment imposed can be up to 6 months.

\section{Animal cruelty in courts}

The administrative offences of animal cruelty are prosecuted in a constantly abundant way. ${ }^{11}$ On the other hand, only few judgments of criminal courts sentencing animal abusers have been taken up to now. ${ }^{12}$ To clarify this fact, the history of our criminal law protection of animals has to be remarked and also the workload of the Czech courts has to be mentioned.

$9 \S 40$ (2) (c) of the Act No. 273/2008 Sb., on the Police of the Czech Republic.

$10 \S \S 302$ and 303 of the Penal Code.

11 The Animal Protection Programme gives special statistical data: e.g. there were almost 450 administrative procedures opened in 2010. See Animal Protection Programme, Situation in 2010, p. 4.

12 Eg. in 2010, a total of 19 persons were criminally prosecuted, 15 persons were charged and 20 persons were convicted for animal cruelty behaviour. Since 1993, when the (previous) Penal Code criminalized cruelty to animals, there have been a total of 681 persons criminally prosecuted and 350 persons have been convicted for cruelty to animals. See Animal Protection Programme, Situation in 2010, p. 4. 
Firstly, the new stricter Penal Code with two types of animal cruelty crimes came in force in January 1, 2010, and thus, wrongs to animals, committed before that date cannot be prosecuted under these stricter provisions. Secondly, the Czech courts are overloaded and a proceeding in court may take several years. Thus, since 2010, there might be an insignificant number of criminal proceedings under way, as regards animal cruelty, which has not been decided yet.

\section{Abused animals}

In case of proven animal cruelty, an administrative authority can take the abused animal from the keeper and place it in a foster care and/or may order the keeper the suspension of those (e.g. business) activities, during which the cruelty was committed. Such a measure can accompany the penalty or other (criminal) punishment. However, there is no possibility within the Czech law in force to prohibit the keeper - animal abuser to keep animals as such. Unfortunately, there have been cases of animal keepers who had been punished for animal cruelty but acquired new animals or moved to another region where they were not known and continued their damnable practices. The ongoing amendment of the AWA plans to entitle veterinary authorities to ban the keeper from having any animals at all or from having certain types of animals if the abuse was proven.

\section{Groundless killing of animals}

Apart from prohibiting all the activities being cruelty to animals, the Czech anti-cruelty legislation is strengthened by a ban on groundless killing animals (here also meaning vertebrates). The AWA gives an exhaustive list of reasons in section 5 that only legitimize killing an animal. ${ }^{13}$ Further, there is a list of prohibited methods of killing animals. ${ }^{14}$ The ban on killing an animal without a legal reason and on killing an animal by a prohibited method apply as a general rules on any person or facility and on any vertebrate of any animal category (companion, farm, etc.). Thus, killing an animal on a ground not mentioned in section 5 (e.g. killing redundant animals, killing stray animals or animals not having a master, killing animals no longer wanted etc.) is illegal. For violation of the ban a person or a facility may be fined up to 500.000 CZK (approx. $€ 20.000$ ).

\footnotetext{
13 To the reasons for a legal killing an animal for example these belong: use of the products of a farm animal; weakness, terminal illness, serious injury, genetic or congenital defect, overall exhaustion or old age of the animal, being its survival accompanied by permanent suffering; immediate threat posed to human by an animal; exercise of the rights of hunting and fishing pursuant to special legislation; imposition of emergency veterinary or sanitary measures for the protection against diseases.

14 Among the prohibited methods of killing animals are for example: drowning or other methods of suffocating; beating to death; stabbing to death or other methods causing undue pain or suffering to an animal; use of adhesives or other similar means causing long lasting restriction of the movement of an animal.
} 


\section{Handling stray animals}

\section{Lost and abandoned animals}

Legal regulation of handling stray and abandoned animals and of operating animal shelters illustrates the Czech legislative approach to companion animals as one of the animal categories. Stray animals may be either lost or abandoned; the will of the proprietor makes the difference between the two eventualities: only who leaves the animal with the intention to get rid of it or to banish it (i.e. to own the animal no longer), abandons the animal. Abandonment of an animal is explicitly prohibited by the $\mathrm{AWA}^{15}$ and may be penalized up to $500.000 \mathrm{CZK}$ (approx. $€ 20.000$ ). Lost animals shall be given back to their owners; however, the identification of animals by microchips which would help to find their owners is not yet generally widespread in the Czech Republic (the duty of dogs' identification may be imposed by municipal decrees ${ }^{16}$ ).

General rules of handling lost (found) objects are set by the Civil Code: any found object, whose owner is not known, is to be transmitted to the municipality in whose area it had been found and further, the owner may claim for getting his or her ownership back within 6 months; if not, the municipality gets the proprietary rights. ${ }^{17}$ As animals are objects in legal sense till 2014, these Civil Code provisions apply also to them. The application of the Civil Code rules on stray animals has both advantages and disadvantages. The bright side of the matter is that there is somebody who is responsible (also financially) for stray animals - the municipalities. They use a network of animal shelters to care for these animals. By contrast, the underside relates to the 6-month period mentioned. This period is being justified by a general principle of protection of proprietary rights. However, in case of animals it is unreasonably long, both for original owners and animals. Original owners usually have, in practice, little interest to take their animals back after several months; mostly due to high costs paid for animals kept in shelters that the owners must reimburse in that case. From the animal point of view, the long period of "blocking" the previous propriety complicates seeking new homes to animals because persons interested in taking an animal from a shelter have to wait for that time. In the new Civil Code, the propriety protecting period mentioned shall be diminished to 2 months in case of found animals.

\section{Animal shelters}

As the municipalities are responsible for animals found within their territory, they are also empowered to establish and operate animal shelters. That does not mean that it is obligatory for every municipality to operate its own shelter; many municipalities have a contract with another municipality having a shelter or with an approved private shelter.

\footnotetext{
${ }^{15} \S 6$ and $\$ 4(1)($ s)oftheAWA.

${ }^{16} \S 13 \mathrm{~b}(2)$ of the AWA. For instance, the city of Prague imposed an obligatory application of microchips on all dogs.

${ }^{17} \S 135$ (1) of the Act No. 40/1964 Sb., previous Civil Code (still in force).
} 
In the Czech Republic, there are nowadays 114 animal shelters; about 60 of them are municipal shelters; most of them are intended only for cats and dogs. ${ }^{18}$

Conditions of animal shelters construction and operation are stipulated by the Veterinary Act. Before building an animal shelter, a permit of a regional veterinary administration is needed (in addition to the building permit) ${ }^{19}$. Any person caring for animals in a shelter must have an expert certificate approving his/her ability to this activity which entails also completing a special course. $^{20}$

\section{Conclusion}

In the Czech Republic, the system of legislation aimed at the protection of animals is wellestablished. Under the new Czech Civil Code, the animals elevated their legal status above objects. The Czech animal protection legislation, whose basis is established by the Animal Welfare Act, covers all vertebrates' protection against cruelty, protection of certain categories of animals kept by humans, and protection of all animals during certain human activities with them. The concept of cruelty to animals is highly-developed in the Czech law so as to cover all conceivable practices leading to animal suffering. The most serious acts of cruelty are criminally prosecuted. The ban on animal cruelty is strengthened by a ban on killing an animal without a legal ground. The responsibility for stray animals is fulfilled by municipal authorities in the Czech Republic. There is a net of both municipal and private animal shelters.

18 The data: January 2012. See the official list of approved animal shelters published by the Ministry of Agriculture at: http://eagri.cz/public/web/mze/ochrana-zvirat/ochrana-zvirat-obecne/adresare-subjektu/seznamschvalenych-utulku.html.

19 $\S 56$ (1) (b) of the Veterinary Act.

20

$\S 42$ (2) of the Veterinary Act. 